\title{
Role of $O$-Acetyl Groups in the Lipopolysaccharide Receptor for Rhizobium Phage 1P
}

\author{
By ELŻBIETA ZAJĄC AND Z. LORKIEWICZ* \\ Institute of Microbiology, M. Curie-Skłodowska University, Akademicka 19, 20-033 Lublin, \\ Poland
}

(Received 22 March 1983; revised 24 May 1983)

\begin{abstract}
Rhizobium trifolii lipopolysaccharide (LPS) preparations lost their receptor properties for phage $1 \mathrm{P}$ after deacetylation by alkali. LPS treated with acetylesterase isolated from Lactobacillus plantarum showed a simultaneous decrease in the amount of acetyl groups and phage receptor activity. The content of $O$-acetyl groups in the LPS of a phage-resistant mutant was significantly decreased when compared to that in LPS from the parent phage-sensitive strain 24SM. Phage 1P could cleave acetyl groups from the extracted LPS without any detectable formation of reducing groups. Binding of phage $1 P$ to the LPS receptor was irreversible. It was demonstrated by electron microscopy that phage DNA was ejected in vitro in the presence of LPS from $R$. trifolii $24 \mathrm{SM}$ but not of that from the phage-resistant mutant.
\end{abstract}

\section{INTRODUCTION}

Various components of the cell envelope are known to serve as receptor sites for bacteriophages in Gram-negative bacteria (Lindberg, 1977). The recognition of the receptor is a highly specific process. The mechanism of interaction of the phage with the receptor has been elucidated for a number of phages but little information is available on phage receptors in Rhizobium. Barnet \& Vincent (1970) suggested that the receptor site for the phages 7, $7 \mathrm{cr}$ and 8 was associated with the O-antigen of Rhizobium. Atkins \& Hayes (1972) detected alterations in LPS and lipoprotein of a $R$. trifolii strain that adsorbed phage poorly. The phage 16-12-1 for Rhizobium lupini was found to be pilus dependent (Lotz \& Pfister, 1975). Depolymerases specific for exopolysaccharides were detected in a number of phages specific for $R$. trifolii (Barnet \& Humphrey, 1975) and R. leguminosarum (Dandekar \& Modi, 1978). We have demonstrated that the receptor specificity for phage $1 \mathrm{P}$ resides in the LPS of $R$. trifolii 24SM (Zajac et al., 1975a). The sites of phage attachment as well as the mechanism of the interaction between the phage and its Rhizobium receptor have not however been determined in detail.

In this report we show that $O$-acetyl groups are essential components in the phage receptor, and that phage 1P cleaves $O$-acetyl groups from isolated LPS.

\section{METHODS}

Bacterial and phage strains. Rhizobium trifolii $24 \mathrm{SM}$ and its derivative 15, resistant to phage $1 \mathrm{P}$ (Zajac et al.. $1975 a$ ) were used. They were grown in medium 4 as described by Zajac et al. (1975a). Phage 1P propagated on $R$. trifolii 24SM was employed in assays of receptor activity of LPS.

$L P S$. This was prepared and deacetylated as described previously (Zając ot al., 1975a).

Gas-liquid chromatography. This was performed as described by Zajac et al. (1975h).

Preparation of acetylesterase. The enzyme was isolated from Lactobacillus plantarum according to Oterholm et al. (1972). Its activity was determined by mixing $5 \mathrm{ml}$ of an homogenized suspension of penta- $O$-acetyl-D-glucose $(0.2 \mathrm{M})$ at $\mathrm{pH} 6.5$ with $0.2 \mathrm{ml}$ of the enzyme preparation (equivalent to $100 \mu \mathrm{g}$ protein $\mathrm{ml}^{-1}$ ) and ancubating at $37^{\mathrm{C}} \mathrm{C}$ for $1 \mathrm{~h}$ with subsequent $\mathrm{pH}$ measurements.

Ahbretiation: LPS, lipopolysaccharide. 
Quantitative assay of $O$-acetyl groups. $O$-Acetyl groups were measured by the procedure of Hestrin (1949) and by gas chromatography (Fromme \& Beilharz, 1978).

Infrared analysis. Samples of LPS ( $3 \mathrm{mg}$; prepared as described by Westphal \& Jann, 1965) in $\mathrm{KBr}$ were analysed in a Zeiss IR 20 apparatus.

Assay of reducing groups. This was done by the procedure of Park \& Johnson (1949), using D-glucose as the standard.

Sonication. LPS of $R$. trifolii $24 \mathrm{SM}$ with attached phage $1 \mathrm{P}$ was sonicated using an MSE sonicator, $150 \mathrm{~W}, 8 \times$ $15 \mathrm{~s}, 0^{\circ} \mathrm{C}$.

Electron microscopy. LPS suspension $\left(2 \mathrm{mg} \mathrm{ml}^{-1}\right)$ was incubated with phage $\left(2 \times 10^{11}\right.$ p.f.u. $\left.\mathrm{ml}^{-1}\right)$ at $37^{\circ} \mathrm{C}$ for $1 \mathrm{~h}$ in the presence of $0.2 \%$ albumin. Then the material was placed on Formvar-coated electron microscope grids. After application of $2 \%(\mathrm{w} / \mathrm{v})$ phosphotungstic acid at $\mathrm{pH} 7.0$ for $2 \mathrm{~min}$ at $4{ }^{\circ} \mathrm{C}$, the grids were dried and examined in a JEM $100 \mathrm{~B}$ electron microscope.

\section{RESULTS}

We had previously shown that receptor sites for phage $1 P$ are located on LPS of $R$. trifolii 24SM (Zajace et al., 1975a). L-Glycero-D-mannoheptose, 3-O-methylheptose, 3,6-di-O-methylheptose and mannose are major sugar components of this LPS (Russa \& Lorkiewicz, 1979), which suggested that heptoses might form part of the phage receptor. However, L-glycero-Dmannoheptose was found to be the major component of LPS from the phage-resistant mutant 15 .

Many phages that bind to LPS have endoglycosidic activity, usually splitting a specific sugar bond in the LPS (Iwashita \& Kanegasaki, 1973; Reske et al., 1973). To test this for the phage 1P, LPS of $R$. trifolii $24 \mathrm{SM}\left(10 \mathrm{mg} \mathrm{ml}^{-1}\right)$ was suspended in $0.01 \mathrm{M}-\mathrm{Tris} / \mathrm{HCl}$ buffer, $\mathrm{pH} 7 \cdot 4$, and incubated with phage $\left(6 \times 10^{10}\right.$ p.f.u. $\left.\mathrm{ml}^{-1}\right)$ for $16 \mathrm{~h}$. Every four hours the amount of reducing groups was determined and compared with results for LPS incubated under the same conditions but without phage. No increase in reducing groups was observed.

In a further search for components of the phage receptor we examined the possible involvement of acetyl groups. The infrared spectrum of LPS of the phage-sensitive strain $R$. trifolii 24SM showed a strong absorption peak at $1740 \mathrm{~cm}^{-1}$ (Fig. 1, A), which is characteristic for ester-bound acetyl groups. The spectrum of the corresponding LPS from the phage-resistant mutant 15 did not show such a peak (Fig. 1, B). The content of $O$-acetyl groups measured by either gas chromatography or the Hestrin procedure was also significantly lower in LPS from mutant 15 than in LPS from strain 24SM (Table 1). This suggested that acetyl groups may be involved in the attachment of the phage to the receptor. Alkali-treated LPS preparations showed a simultaneous decrease in $O$-acetyl groups and phage receptor activity (Table 1).

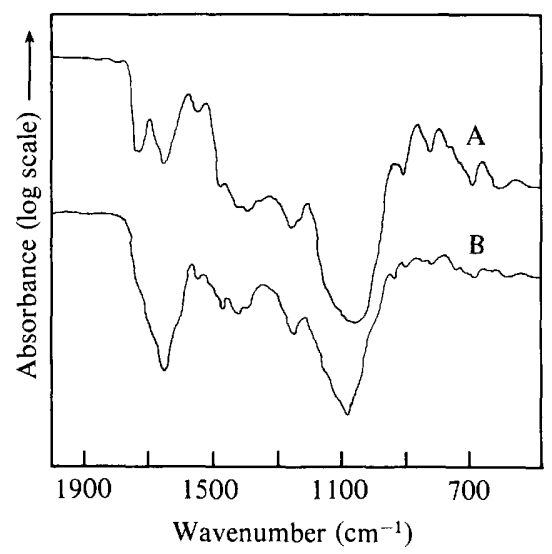

Fig. 1. Infrared absorption spectra of LPS isolated from the phage-sensitive strain 24SM (A) and that of the phage-resistant mutant $15(\mathrm{~B})$. The $\mathrm{C}=\mathrm{O}$ stretching vibration of an $O$-acetyl group gives very strong absorption in the region $1725-1749 \mathrm{~cm}^{-1}$. The peak of acetyl group frequencies was not detected in LPS from mutant 15. 
Table 1. Content of $O$-acetyl groups in LPS preparations and their phage-inactivating capacity $O$-Acetyl groups ( $\mu$ mol per mg LPS)

LPS from:

\section{Strain 24SM}

Strain 24SM (+0.02 M-NaOH)* Mutant 15

$\begin{array}{ccc}\begin{array}{c}\text { Gas-liquid } \\ \text { chromatography }\end{array} & \begin{array}{c}\text { Hestrin } \\ \text { procedure }\end{array} & \begin{array}{c}\text { Percentage of phage inactivation } \\ \text { per } \mu \text { LPS } \dagger\end{array} \\ 0.34 & 0.3 & 81 \\ 0.04 & - & 3 \\ 0.078 & 0.092 & 0\end{array}$

* Treatment was for $1 \mathrm{~h}$ at $37^{\circ} \mathrm{C}$. $37^{\circ} \mathrm{C}$.

$\uparrow$ Final concentration of LPS was $1 \mu \mathrm{g} \mathrm{ml}^{-1}$ and of phage $1 \mathrm{P} 3 \times 10^{3}$ p.f.u. $\mathrm{ml}^{-1}$; incubation was for $15 \mathrm{~min}$ at

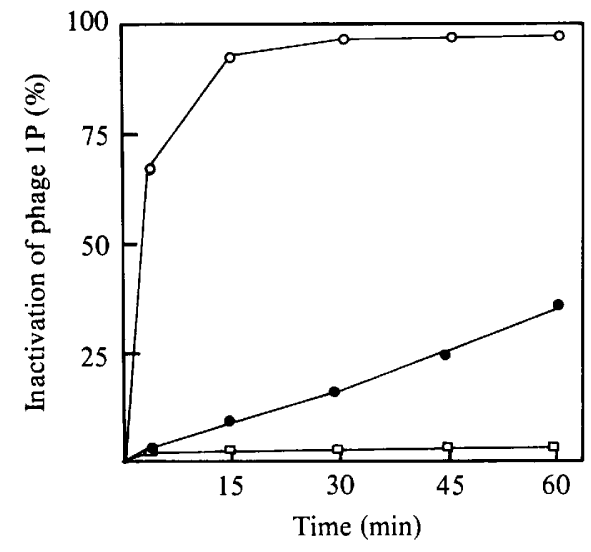

Fig. 2

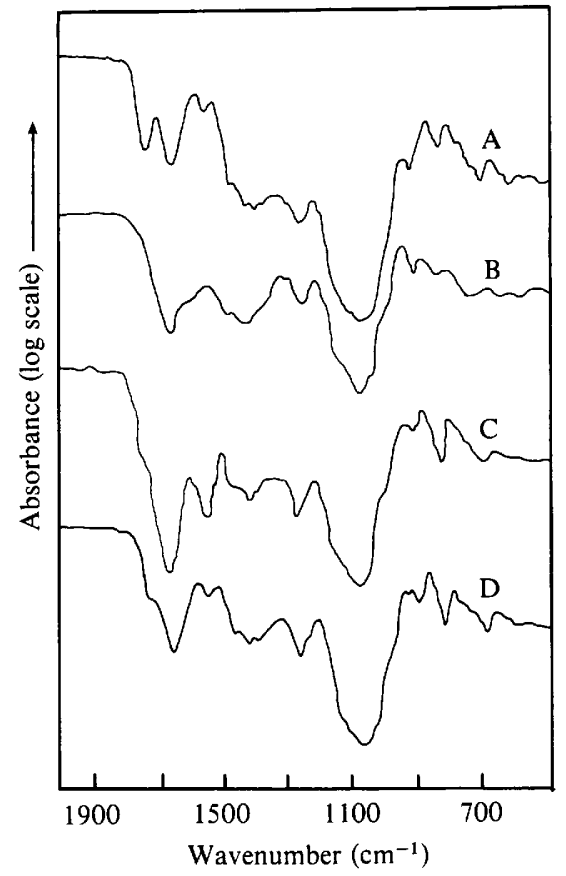

Fig. 3

Fig. 2. Inactivation of phage $1 P$ by acetylesterase-treated LPS from strain 24SM. O, Untreated LPS; , LPS treated with acetylesterase (equivalent to $100 \mu \mathrm{g}$ protein per mg LPS), $1 \mathrm{~h}, 37^{\circ} \mathrm{C} ; \square$, phage 1 P incubated with acetylesterase, $1 \mathrm{~h}, 37^{\circ} \mathrm{C}$. For testing phage receptor activity of LPS the final concentration of LPS was $5 \mu \mathrm{g} \mathrm{ml}^{-1}$ and of phage $1 \mathrm{P} 3 \times 10^{3}$ p.f.u. $\mathrm{ml}^{-1}$

Fig. 3. Infrared spectra of LPS from strain 24SM : A, untreated; B, pretreated with $0.02 \mathrm{M}-\mathrm{NaOH}, 1 \mathrm{~h}$, $37^{\circ} \mathrm{C} ; \mathrm{C}$, incubated with acetylesterase (equivalent to $100 \mu \mathrm{g}$ protein per mg LPS), $1 \mathrm{~h}, 37^{\circ} \mathrm{C} ; \mathrm{D}$, incubated with phage $1 \mathrm{P}\left(6 \times 10^{10}\right.$ p.f.u. per $\mathrm{mg}$ LPS $), 1 \mathrm{~h}, 37^{\circ} \mathrm{C}$.

Alkaline deacetylation is a rather drastic procedure, which might lead to additional LPS alterations, especially to hydrolysis of some ester-bound fatty acids and to substitution of glycosidic bonds by ester linkages at carbons 3 and 6 . We therefore used a more specific technique of deacetylation by acetylesterase (see Methods). After the Rhizobium LPS had been incubated with the enzyme for $1 \mathrm{~h}$, a significant decrease in its phage receptor activity was observed (Fig. 2). In a control sample of phage 1P incubated with acetylesterase the virus titre remained unaltered. The spectrum of the LPS treated with the enzyme showed a decline in absorption at $1740 \mathrm{~cm}^{-1}$.

We then tested whether phage $1 \mathrm{P}$ actually deacetylated its receptor, by incubating the LPS with phage 1P under the conditions used in experiments testing for the appearance of new 

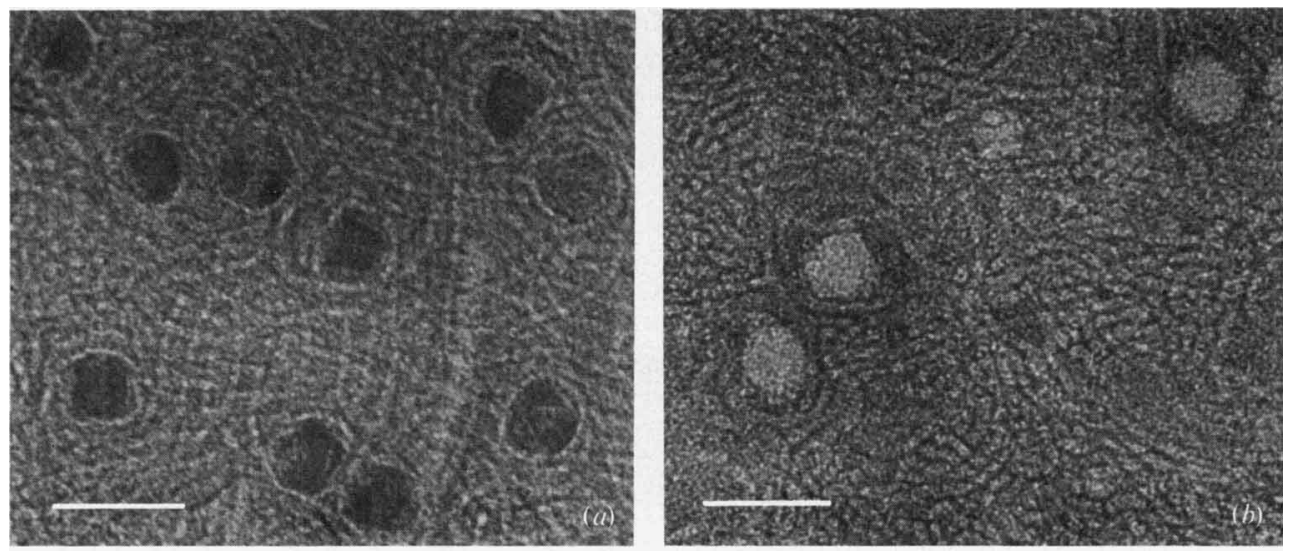

Fig. 4. (a) Electron micrograph of phage 1P particles interacting with LPS from strain 24SM; the phage DNA is ejected. (b) Phage $1 P$ particles incubated with LPS from the phage-resistant mutant 15 ; the phage particles are filled with DNA. The bar markers represent $0 \cdot 1 \mu \mathrm{m}$.

reducing groups. The incubated material was analysed by infrared spectrophotometry. A significant decrease in the content of acetyl groups was observed compared with the untreated LPS preparation, demonstrating that the phage 1P did deacetylate the LPS (Fig. 3).

Binding of phage $1 \mathrm{P}$ to the LPS of strain 24SM was irreversible, as indicated by the failure to release active phage by Triton X-100, sonication or blending, or by transfer of LPS with adsorbed phage $1 \mathrm{P}$ from $4{ }^{\circ} \mathrm{C}$ to $37^{\circ} \mathrm{C}$. This suggested that the in vitro reaction of phage $1 \mathrm{P}$ with LPS resulted in the ejection of phage DNA. This was confirmed by electron microscopy: empty ghosts of phage $1 P$ were found in the preparation of phage $1 P$ incubated with LPS from strain 24SM (Fig. 4a), whereas phage particles incubated with LPS from mutant 15 were filled with DNA (Fig. $4 b$ ).

\section{DISCUSSION}

Bacteriophage receptors have been found in the LPS of numerous representatives of Salmonella (Iwashita \& Kanegasaki, 1973, 1975, 1976; Kanegasaki \& Wright, 1973), Shigella (Przondo-Hessek et al., 1974; Przondo-Hessek \& Romanowska, 1978; Romanowska et al., 1976), Pseudomonas (Jarrel \& Kropiński, 1977; Meadow \& Wells, 1978) and Rhizobium (Zając et $a l ., 1975 a, b)$. Phages $\varepsilon^{15}, \varepsilon^{34}, \mathrm{~g} 341$ and P22 attach to the $O$-side chains of Salmonella. The linkage between successive repeating units is thought to be an essential component of the receptor (Iwashita \& Kanegasaki, 1975; Reske et al., 1973).

The purpose of the present study was to determine the essential components of the receptor for Rhizobium phage 1P, and to investigate the mechanism of the phage-receptor interaction. We had previously found that the receptor for phage $1 \mathrm{P}$ resided in the LPS of $R$. trifolii $24 \mathrm{SM}$. LGlycero-D-mannoheptose was the major component of the LPS of $R$. trifolii 24SM (Zajac et al., $1975 b$ ). Analysing various LPS preparations of $R$. trifolii and $R$. leguminosarum we noticed some correlation between the content of L-glycero-D-mannoheptose and the ability of LPS to inactivate phage $1 \mathrm{P}$. Furthermore, degradation of heptose by oxidation with $\mathrm{NaIO}_{4}$ reduced the capacity of LPS to bind (unpublished results). Tamaki et al. (1971) demonstrated that in Escherichia coli $\mathrm{K} 12$, susceptibility to phage T7 was dependent on the heptose in the core of LPS. However, in further studies these authors found that some heptose-defective mutants were also susceptible to the phage, suggesting that some factor in LPS other than heptose was required for phage $\mathrm{T} 7$ adsorption. We observed that the phage-resistant mutant 15 , derived from $R$. trifolii 24SM, had 5\% less L-glycero-D-mannoheptose than its parent, but this can hardly be a significant difference (Zając et al., 1975b). 
Our further studies (Zając et al., 1975a; Russa et al., 1982) indicated that there is an LPS component other than heptose which is needed for phage attachment. Since phage 1P did not have endoglycosidic activity we examined in detail the role of acetyl groups in phage IP adsorption. Acetyl groups are essential for the attachment of numerous phages. Shaw \& Chatterjee (1971) found that $O$-acetyl groups were components of the bacteriophage 52A receptor on Staphylococcus aureus cell walls. Phage c 341 was shown to cleave acetyl groups from Salmonella anatum $O$-side chains (Iwashita \& Kanegasaki, 1976). It was also found that Viphages I, II and III had deacetylase activity (Taylor, 1965; Szczeklik \& Taylor, 1973; Beilharz et al., 1978). Phage E79 infected Pseudomonas aeruginosa PAO only if its LPS contained acetyl groups (Jarrel \& Kropiński, 1977). In the present study we detected a significant decrease in $O$ acetyl groups in LPS of the phage-resistant mutant 15. LPS preparations of $R$. trifolii 24SM lost their capacity for phage $1 \mathrm{P}$ inactivation after alkaline deacetylation. Although the alkaline deacetylation of LPS was confirmed by infrared analysis and gas chromatography, some other alterations of LPS might occur which could affect phage receptors. Thus the involvement of acetyl groups was also examined by application of the specific enzyme acetylesterase, which decreased the phage receptor activity of the LPS. Phage 1P adsorbs irreversibly to the LPS receptor in host cells.

It is concluded that $O$-acetyl groups are essential for phage $1 \mathrm{P}$ attachment. During this process phage $1 P$ deacetylates its LPS receptor.

This work was supported by the Polish Academy of Science within the project 09.7. The authors wish to thank Dr R. Russa for helpful advice, T. Urbanik for preparation and analyses of LPS and A. Choma for determinations of acetyl groups. Thanks are also due to Dr Z. J. Ordal from Illinois University, Urbana, for providing Lactobacillus plantarum. We thank Dr T. Krzywy for the electron micrographs.

\section{REFERENCES}

AtKIns, G. J. \& HaYes, A. H. (1972). Surface changes in a strain of Rhizobium trifolii on mutation to bacteriophage resistance. Journal of General Microbiology 73, 273-278.

BARNET, Y. M. \& HuMPHREY, B. (1975). Exopolysaccharide depolymerases induced by Rhizobium bacteriophages. Canadian Journal of Microbiology 21, 16471650.

Barnet, Y. M. \& Vincent, J. M. (1970). Lysogenic conversion of Rhizobium trifolii. Journal of General Microbiology 61, 319-325.

Beilharz, H., Kwiatkowski, B. \& Stirm, S. (1978). On the deacetylase activity of Vi bacteriophage III particles. Acta biochimica polonica 25, 207-219.

DANDEKAR, A. M. \& MoDI, V. V. (1978). Interaction between Rhizobium japonicum phage $\mathrm{M}-1$ and its receptor. Canadian Journal of Microbiology 24, 685688.

Fromme, I. \& BeIlharz, H. (1978). Gas chromatographic assay of total and $O$-acetyl groups in bacterial lipopolysaccharides. Analytical Chemistry 84, 347-353.

Hestrin, S. (1949). The reaction of acetylcholine and other carboxylic acid derivatives with hydroxylamine and its clinical application. Journal of Biological Chemistry 180, 249-261.

IWAShita, S. \& Kanegasaki, S. (1973). Smooth specific phage adsorption: endorhamnosidase activity of tail parts of P22. Biochemical and Biophysical Research Communications 55, 403-409.

IWASHITA, S. \& KaNEGASAKI, S. (1975). Release of O antigen polysaccharide from Salmonella newington by phage $\varepsilon^{34}$. Virology 68, 27-34.
IWASHITA, S. \& KANEGASAKI, S. (1976). Deacetylation reaction catalyzed by Salmonella phage c341 and its baseplate parts. Journal of Biological Chemistry 251, $5361-5365$.

JARREL, K. \& KROPIŃSKI, A. M. (1977). Identification of the cell wall receptor for bacteriophage E79 in Pseudomonas aeruginosa strain PAO. Journal of Virology 23, 461-466.

Kanegasaki, S. \& Wright, A. (1973). Studies on the mechanism of phage adsorption: interaction between phage $\varepsilon^{15}$ and its cellular receptor. Virology 52 , $160-173$.

LINDBERG, A. A. (1977). Bacterial surface carbohydrates and bacteriophage adsorption. In Surface Carbohydrates of the Prokaryotic Cell, pp. 289-356. Edited by I. W. Sutherland. London: Academic Press.

Lotz, W. \& Pfister, H. (1975). Attachment of a longtailed Rhizobium bacteriophage to the pili of its host. Journal of Virology 16, 725-728.

MEADOW, P. M. \& Wells, P. L. (1978). Receptor sites for R-type pyocins and bacteriophage E79 in the core part of the lipopolysaccharide of Pseudomonas aeruginosa PAC1. Journal of General Microbiology 108, 339-343.

Oterholm, A., WrITTER, L. D. \& ORdal, Z. J. (!972). Purification and properties of an acetyl ester hydrolase (acetylesterase) from Lactobacillus plantarum. Journal of Dairy Science 55, 8-13.

PaRK, J. T. \& Johnson, M. J. (1949). A submicrodetermination of glucose. Journal of Biological Chemistry 181, 149-151.

Przondo-Hessek, A. \& Romanowska, E. (1978). 
Lipopolysaccharides of Shigella flexnerii 6 as phage receptors. Acta microbiologica polonica 27, 97-102.

Przondo-Hessek, A., MulczyK, M. \& WitKowska, D. (1974). An attempt at the identification of phage receptors in Shigella flexnerii. Acta microbiologica polonica 23, 291-300.

Reske, K., Wallenfels, B. \& JanN, K. (1973). Enzymatic degradation of O-antigenic lipopolysaccharides by coliphage $\Omega 8$. European Journal of Biochemistry 36, 167-171.

Romanowska, E., Ługowski, C. \& MulczyK, M. (1976). Lipopolysaccharide immunoadsorbents and their application to affinity chromatography of $\mathrm{O}$ antibodies and specific phages. FEBS Letters 66, 8285.

RUSSA, R. \& LORKIEwICZ, Z. (1979). O-Methylheptoses in lipopolysaccharides of Rhizobium trifolii 24SM. FEMS Microbiology Letters 6, 71-74.

Russa, R., Urbanik, T., Kowalczuk, E. \& LoRKIEWICZ, Z. (1982). Correlation between the occurrence of plasmid pUCS202 and lipopolysaccharide alterations in Rhizobium. FEMS Microbiology Letters 13, $161-165$.

Shaw, D. R. D. \& Chatterjee, A. N. (1971). O-Acetyl groups as a component of the bacteriophage receptor on Staphylococcus aureus cell walls. Journal of Bacteriology 108, 584-585.

SzCZEKLIK, H. \& TAYLOR, A. (1973). The presence of Vi-polysaccharide deacetylase in three morphologically different Vi-bacteriophages. Bulletin of the Institute of Maritime and Tropical Medicine in Gdynia 24, 165-167.

Tamaki, S., Sato, T. \& Matsuhashi, M. (1971). Role of lipopolysaccharides in antibiotic resistance and bacteriophage adsorption of Escherichia coli $\mathrm{K}-12$. Journal of Bacteriology 105, 968-975.

TAYLOR, K. (1965). Enzymatic deacetylation of Vipolysaccharide by Vi-phage II. Biochemical and Biophysical Research Communications 20, 752-757.

WeSTPHAL, O. \& JANN, K. (1965). Bacterial lipopolysaccharides. Extraction with phenol-water and further applications of the procedure. Methods in Carbohydrate Chemistry 5, 83-91.

ZAJąC, E., Russa, R. \& LoRkIEWICZ, Z. (1975a). Lipopolysaccharide as receptor for Rhizobium phage 1P. Journal of General Microbiology 90, 365-367.

ZaJąC, E., Russa, R. \& LoRkIEWICZ, Z. (1975b). Studies on phage $1 \mathrm{P}$ receptors in Rhizobium trifolii and Rhizobium leguminosarum. Acta microbiologica polonica 4, 181-188. 